\title{
Antenatal Medical Therapies to Improve Lung Development in Congenital Diaphragmatic Hernia
}

\author{
Aidan Kashyap ${ }^{1,2}$ Philip DeKoninck, MD, PhD ${ }^{1,2}$ Kelly Crossley, PhD ${ }^{1,2}$ Marta Thio, MD, PhD $3,4,5,6$ \\ Graeme Polglase, $\mathrm{PhD}^{1,2}$ Francesca Maria Russo, $\mathrm{MD}^{7,8}$ Jan Deprest, MD, $\mathrm{PhD}^{7,8,9}$ \\ Stuart Hooper, $\mathrm{PhD}^{1,2}$ Ryan Hodges, MD, $\mathrm{PhD}^{1,2,10}$
}

${ }^{1}$ The Ritchie Centre, Hudson Institute of Medical Research,

Address for correspondence Ryan Hodges, MD, PhD, Monash Medical Melbourne, Australia

2 Department of Obstetrics and Gynaecology, Monash University, Centre, 246 Clayton Road, Clayton, Victoria 3168, Australia Melbourne, Australia

${ }^{3}$ Newborn Research Centre, The Royal Women's Hospital, Melbourne, Australia

${ }^{4}$ Centre of Research Excellence in Newborn Medicine, Murdoch Children's Research Institute, Melbourne, Australia

${ }^{5}$ Department of Obstetrics and Gynaecology, The University of Melbourne, Melbourne, Australia

6 PIPER - Neonatal Retrieval Services Victoria, The Royal Children's Hospital, Melbourne, Australia

${ }^{7}$ Division of Woman and Child, Department of Obstetrics and Gynaecology, University Hospitals Leuven, Leuven, Belgium

${ }^{8}$ Department of Development and Regeneration, Cluster Woman and Child, Faculty of Medicine, KU Leuven, Belgium

9 Institute for Women's Health, University College London Hospital, London, United Kingdom

10 Monash Women's Service, Monash Health, Melbourne, Australia (e-mail: Ryan.Hodges@monash.edu).

\section{Am J Perinatol}

\author{
Abstract \\ Keywords \\ - congenital \\ diaphragmatic hernia \\ - antenatal therapy \\ - fetal \\ - sildenafil \\ - pulmonary \\ hypertension of the \\ newborn \\ - pulmonary \\ hypoplasia
}

Congenital diaphragmatic hernia $(\mathrm{CDH})$ is a birth defect characterized by failed closure of the diaphragm, allowing abdominal viscera to herniate into the thoracic cavity and subsequently impair pulmonary and vascular development. Despite improving standardized postnatal management, there remains a population of severe $\mathrm{CDH}$ for whom postnatal care falls short. In these severe cases, antenatal surgical intervention (fetoscopic endoluminal tracheal occlusion [FETO]) may improve survival; however, FETO increases the risk of preterm delivery, is not widely offered, and still fails in half of cases. Antenatal medical therapies that stimulate antenatal pulmonary development are therefore interesting alternatives. By presenting the animal research underpinning novel antenatal medical therapies for $\mathrm{CDH}$, and considering the applications of these therapies to clinical practice, this review will explore the future of antenatal CDH management with a focus on the phosphodiesterase- 5 inhibitor sildenafil.
Congenital diaphragmatic hernia $(\mathrm{CDH})$ is a birth defect characterized by failed closure of the diaphragm, allowing abdominal viscera to herniate into the thoracic cavity and subsequently impair pulmonary and vascular development. ${ }^{1}$ Normal pulmonary development is predominantly driven by mechanical stretch, ${ }^{2,3}$ fetal breathing movements, ${ }^{4,5}$ and complex interactions between blood vessels and airways. ${ }^{6}$ In $\mathrm{CDH}$, pulmonary development is impaired, causing pulmonary hypoplasia and clinically resulting in respiratory insufficiency and pulmonary hypertension in the newborn, ${ }^{7}$ received

July 10, 2017

accepted after revision

December 5, 2017
Copyright $\odot$ by Thieme Medical Publishers, Inc., 333 Seventh Avenue, New York, NY 10001, USA. Tel: +1(212) 584-4662.
DOI https://doi.org/ 10.1055/s-0037-1618603. ISSN $0735-1631$. 
which are major determinants of morbidity and mortality in $\mathrm{CDH}_{\text {infants. }}^{8}$

Despite in utero referral, centralization of care and standardization of postnatal management, ${ }^{9}$ there remains a population of severe $\mathrm{CDH}$ infants with extremely poor survival chances. ${ }^{8,10}$ Overall, 20 to $30 \%$ of the 1 in 3,000 live-born neonates with isolated $\mathrm{CDH}$ still die, and in severe cases, survival is less than $15 \%{ }^{11}$ In these cases, antenatal interventions may improve outcomes by increasing lung growth and possibly improving pulmonary structural development. ${ }^{12}$ Until now, most strategies are based on fetal surgical interventions, and the current experimental approach is by fetoscopic endoluminal tracheal occlusion (FETO). ${ }^{12}$ Though there is an apparent increase in survival rates, the success of fetal surgery is limited by technical feasibility, the major complication of preterm birth, and the requirement for patient access to experienced fetal surgical centres. ${ }^{12}$ Apart from that, in the best case scenario up to $40 \%$ of fetuses will eventually not survive because of limited pulmonary response. ${ }^{13}$ Because of these limitations, much research effort has been directed toward investigating alternative antenatal medical therapies. In 2015, Eastwood et al published a systematic overview of antenatal medical therapies under investigation in animal models of $\mathrm{CDH}$, predominantly in the nitrofen rat model. ${ }^{14}$ Several recent promising findings, particularly in relation to phosphodiesterase- 5 inhibitors, warrant an update of this review that will take a more descriptive approach.

By presenting the animal research underpinning novel antenatal medical therapies for $\mathrm{CDH}$, and considering the applications of these therapies to clinical practice, we will explore the future of antenatal $\mathrm{CDH}$ management.

\section{Pathophysiology of Congenital Diaphragmatic Hernia}

The pathogenesis of $\mathrm{CDH}$ remains unclear; however, the leading hypothesis is that abnormal development of the diaphragm's amuscular mesenchymal component results in an incomplete migration platform for muscle precursors. ${ }^{15}$ The defect predominantly occurs on the left side (80-90\%), the majority of which are located posterolaterally (70\%). ${ }^{1}$ An incomplete diaphragm allows herniation of abdominal contents into the thoracic cavity from the embryonic phase onward, from then disturbing further lung development.

The process by which CDH impairs pulmonary development is not entirely understood. The classical hypothesis is that herniating abdominal viscera occupies space in the thoracic cavity, placing external pressure on the developing lungs and interfering with fetal breathing movements. ${ }^{16}$ Alternatively, Keijzer et al proposed the "dual-hit" hypothesis: early in development a genetic or environmental insult prevents closure of the diaphragm and also impairs bilateral pulmonary branching morphogenesis. Following this initial insult, the herniating abdominal viscera further contributes to pulmonary hypoplasia. ${ }^{17}$

In addition to reduced lung size and airway complexity, ${ }^{7}$ increased muscularization and decreased cross-sectional area of distal pulmonary vessels lead to increased pulmonary vascular resistance. ${ }^{18}$ Normally at birth, air entry drives lung liquid out of the airways and into the surrounding tissue, which triggers a decrease in pulmonary vascular resistance and subsequent increase in pulmonary blood flow and oxygenation. ${ }^{19,20}$ In contrast, pulmonary vascular resistance remains high at birth in most neonates with $\mathrm{CDH}$, often leading to clinically significant pulmonary hypertension. ${ }^{21}$ This adds significant postnatal morbidity, as in most cases, infants with pulmonary hypertension need mechanical ventilation to treat pulmonary hypertension-induced hypoxemia, which may contribute to further lung injury. Neonates with $\mathrm{CDH}$ and severe pulmonary hypertension have mortality rates ranging from 56.1 to $100 \% .^{8,10,22}$ Therefore, preventing pulmonary hypertension by identifying and treating these patients in utero may be key to improving their survival.

\section{Limitations of Antenatal Surgical Therapies for Congenital Diaphragmatic Hernia}

Tracheal ligation was first described as a method of enhancing lung growth by preventing egress of lung liquid, in 1965. ${ }^{23}$ After intensive preclinical experimentation, tracheal occlusion was first achieved clinically in an open procedure that required hysterotomy and fetal neck dissection. ${ }^{24}$ This open procedure was associated with severe neurological morbidity and a survival rate of 33\%; therefore, efforts were made to investigate less invasive approaches. ${ }^{24}$ Initially, this included a maternal laparotomy and multiple trocar insertions, but gradually this evolved to a percutaneous single port procedure that was optimized by the FETO consortium. ${ }^{25-27}$

In 2009, the FETO consortium published its experience of using FETO for isolated CDH in more than 200 cases. Indeed, survival rates were higher than was anticipated based on historical controls. However, despite the use of keyhole surgery (3.3 mm single trocar), preterm premature rupture of membranes (47.1\%) and subsequently preterm birth (median gestational age at delivery: 35.3 weeks) are still important complications. ${ }^{12}$ Nevertheless, these promising results lead to two large multicenter randomized trials evaluating the efficacy of FETO (www.totaltrial.eu). ${ }^{28,29}$ Within these trials, the balloon is inserted at 27 to 30 weeks of gestation in severe cases of $\mathrm{CDH}$ and 30 to 32 weeks of gestation in moderate cases. $^{30}$

The current clinical strategy includes reversal of tracheal occlusion because experimental work has shown that if the balloon is not removed, then surfactant deficiency results from transdifferentiation of surfactant-producing type II alveolar epithelial cells into nonsurfactant-producing type I cells. $^{31-33}$ Balloon removal also allows the patient to return to the institution where she would normally deliver and potentially have a vaginal delivery. Elective balloon removal is typically scheduled for 34 weeks of gestation either by ultrasound-guided percutaneous puncture or by fetoscopy. ${ }^{34}$ A recent series described that in experienced centers in $96.8 \%$ of elective procedures, the balloon can be successfully 
removed. ${ }^{35}$ In 28 to $43 \%$ of cases, however, obstetrical complications and, in particular, threatened preterm labor prompted an emergent removal of the balloon. ${ }^{12,35}$ In this emergency setting, if release cannot be performed by percutaneous puncture or fetoscopy, extraction may be required on placental circulation. Balloon extraction was initially performed as a formal ex utero intrapartum procedure, yet now is safely done during a modified cesarean section. ${ }^{12,35,36}$ As a last resort, the balloon can be removed postnatally with a specially designed tracheoscope or percutaneous puncture. ${ }^{34}$ Difficulties in balloon removal played a major contribution to neonatal death in 10 of the 210 cases performed by the FETO consortium; ${ }^{12}$ therefore, it is recommended that a 24/7 team of experienced clinicians are on-call to deal with emergency balloon removal. ${ }^{30}$ This limits the use of FETO to high-volume tertiary referral centers.

Finally, the success of FETO appears dependent on preexisting lung size, potentially because smaller lungs have less lung liquid secreting epithelium. ${ }^{12}$ Furthermore, as lung liquid secretion ceases when the fetal lung's intraluminal pressure reaches $\sim 6 \mathrm{~mm} \mathrm{Hg}^{37}$ if the pressure required to expand the hypoplastic lung exceeds $6 \mathrm{~mm} \mathrm{Hg}$, then FETO will not increase lung expansion. These limitations indicate that further antenatal medical therapies are required to address the remaining morbidity and mortality of severe $\mathrm{CDH}$, preferentially medical in nature to reduce invasiveness and make prenatal therapy more accessible.

\section{Antenatal Medical Therapies for Congenital Diaphragmatic Hernia}

This review will predominantly focus on the antenatal medical therapies that show the most promise in correcting pulmonary hypoplasia and pulmonary hypertension in $\mathrm{CDH}$ -corticosteroids, retinoids, and phosphodiesterase-5 inhibitors. Several other medical therapies for $\mathrm{CDH}$ have been investigated and are extensively reviewed by Eastwood et al. $^{14}$

Recently, there have also been promising results using cell-based therapies to improve pulmonary development in $\mathrm{CDH}^{38-40}$ In contrast to medical therapies, cell-based therapies may not only prevent further lung injury but also repair established disease. ${ }^{41}$ Regenerative medicine could contribute to the management of $\mathrm{CDH}$ on various levels, as recently reviewed by De Coppi and Deprest, ${ }^{42}$ but it is beyond the scope of this article.

\section{Corticosteroids}

The only antenatal medical therapy for CDH studied in a human randomized controlled trial is the corticosteroid betamethasone, which was administered by intramuscular injection to mothers at 34 weeks of gestation (two doses of $12.5 \mathrm{mg} 24$ hours apart, then $12.5 \mathrm{mg}$ weekly for 2 weeks). ${ }^{43}$ An interim analysis after 32 completed cases (17 steroid, 15 placebo) showed no differences in perinatal mortality, mechanical ventilation time, or days of hospital admission. Based on these preliminary results, the data safety monitoring committee decided to end the study prematurely, as it was determined that to demonstrate any significant difference more than 1,700 fetuses with a prenatally diagnosed $\mathrm{CDH}$ would need to be enrolled. The experience of this trial highlights that as a rare condition in which only a subgroup of the most severely afflicted will obtain benefit from antenatal therapy, randomized controlled trials of $\mathrm{CDH}$ are only feasible if conducted in a co-ordinated world-wide multicenter approach.

\section{Mechanism of Action}

Research efforts initiated by Liggins and Howie ${ }^{44}$ and summarized by Ballard and Ballard ${ }^{45}$ demonstrated that the timing of fetal lung maturation correlates with a physiological increase in circulating corticosteroids, and that administering antenatal exogenous corticosteroids accelerates lung development. Antenatal corticosteroids improve neonatal lung function by acting at a transcriptional level. The mechanism of action was initially described as accelerating the maturation of alveolar structure, cell differentiation, surfactant production, and lung liquid clearance mechanisms; ${ }^{46}$ however, findings from glucocorticoid receptor knockout mice indicate that glucocorticoids predominantly improve lung maturation by restraining hyperproliferation of the interalveolar septum and surrounding mesenchyme. ${ }^{47,48}$ The benefits of antenatal corticosteroids to lung development have led to their extensive use to reduce disease associated with developmental immaturity in the setting of threatened preterm delivery, recently summarized by Kemp et al. ${ }^{49}$ Observations by George et al that infants with $\mathrm{CDH}$ had structurally immature lungs suggested that antenatal corticosteroids may also improve lung development in the setting of $\mathrm{CDH}^{50}$

\section{Pharmacokinetics and Bioavailability}

The efficacy of antenatal corticosteroids for CDH was first established in successful rat, ${ }^{51-54}$ rabbit, $^{55-57}$ and sheep ${ }^{58,59}$ models ( - Table 1 ). These animal studies predominantly investigated betamethasone and dexamethasone, fluorinated synthetic corticosteroids that cross the placenta from maternal to fetal circulation, have minimal mineralocorticoid activity and are weak immunosuppressants. ${ }^{49}$ In the setting of threatened preterm delivery, betamethasone is administered intramuscularly in two $12 \mathrm{mg}$ doses, 24 hours apart. ${ }^{60}$ This generates a maximum fetal plasma concentration of $\sim 20 \mathrm{ng} / \mathrm{mL}, 1$ to 2 hours after treatment, with a half-life of 12 hours in the fetal circulation. ${ }^{45}$ The maximum maternal plasma concentration of $\sim 100 \mathrm{ng} / \mathrm{mL}$ is reached 1 hour after treatment, with a halflife of 6 hours.

\section{Safety}

Antenatal corticosteroids are extensively used to improve fetal lung maturation for women with threatened preterm delivery, thereby reducing neonatal mortality and respiratory morbidity. A recent Cochrane review including 30 randomized controlled trials found that antenatal corticosteroid treatment does not increase the risk of neurodevelopmental delay, chorioamnionitis, endometritis, or maternal 
Antenatal Medical Therapies to Improve Lung Development in CDH Kashyap et al.

Table 1 Antenatal steroids in experimental animal models of congenital diaphragmatic hernia

\begin{tabular}{|c|c|c|}
\hline Domain & \multicolumn{2}{|l|}{ Impact of antenatal steroids } \\
\hline Gross lung size (LBWR) & \multicolumn{2}{|l|}{ No significant effect ${ }^{51-53,55,56,63}$} \\
\hline \multirow[t]{3}{*}{ Airway morphometry } & \multicolumn{2}{|l|}{$\downarrow$ Septal thickness $51,53,58,59$} \\
\hline & \multicolumn{2}{|l|}{$\uparrow$ Airspace volume $51,53,58,59$} \\
\hline & \multicolumn{2}{|l|}{$\uparrow$ Radial alveolar count ${ }^{58}$} \\
\hline \multirow[t]{2}{*}{ Vascular Morphometry } & \multicolumn{2}{|l|}{$\downarrow$ Medial wall thickness ${ }^{53,56,57}$} \\
\hline & \multicolumn{2}{|l|}{$\uparrow$ Distal vessel number ${ }^{56}$} \\
\hline \multirow[t]{10}{*}{ Biochemical changes } & \multirow[t]{2}{*}{ Unclear effect on surfactant protein expression } & No change ${ }^{51}$ \\
\hline & & $\uparrow^{64}$ \\
\hline & \multirow[t]{2}{*}{ Unclear effect on eNOS expression } & No change ${ }^{51}$ \\
\hline & & $\uparrow^{53}$ \\
\hline & \multirow[t]{2}{*}{ Unclear effect on growth factors and proliferation markers } & $\uparrow$ bFGF, PDGF, TGF- $\beta 1$ expression ${ }^{54}$ \\
\hline & & $\downarrow \mathrm{K}_{\mathrm{i}}-67$ and PCNA mRNA ${ }^{63}$ \\
\hline & \multirow[t]{2}{*}{ Unclear effect on glycogen levels } & No change $\mathrm{e}^{55}$ \\
\hline & & $\downarrow^{59}$ \\
\hline & \multirow[t]{2}{*}{ Increases VEGF and VEGF receptor expression } & $\uparrow^{52,67}$ \\
\hline & & $\downarrow^{53}$ \\
\hline \multirow[t]{2}{*}{ Physiological changes } & \multicolumn{2}{|l|}{$\uparrow$ Postductal $\mathrm{PaO}_{2}^{59}$} \\
\hline & \multicolumn{2}{|l|}{$\uparrow$ Dynamic compliance $^{59}$} \\
\hline
\end{tabular}

Abbreviations: bFGF, basic fibroblast growth factor; eNOS, endogenous nitric oxide synthase; LBWR, lung-to-body weight ratio; mRNA, messenger ribonucleic acid; PCNA, proliferating cell nuclear antigen; PDGF, platelet-derived growth factor; TGF- $\beta 1$, transforming growth factor $\beta 1$; VEGF, vascular endothelial growth factor.

death, and reduces the risk of perinatal and neonatal death. ${ }^{61}$ It found no definitive evidence suggesting differences between a single course and weekly repeated corticosteroids; however, the Maternal-Fetal Medicine Units Network raises concerns regarding a nonstatistically significant ( $p=0.12$ ) association between multiple doses of antenatal corticosteroids and cerebral palsy. ${ }^{62}$

\section{Effects on Airways in Diaphragmatic Hernia}

Antenatal corticosteroids appear to accelerate lung maturation, but there are concerns that this may be at the expense of lung growth. Accelerated lung maturation is indicated by decreased septal thickness, increased airspace volume, and increased radial alveolar count. ${ }^{51,53,58,59}$ On the contrary, lung:body weight ratio appears unaffected by antenatal corticosteroids, and messenger ribonucleic acid (mRNA) expression of proliferation markers $\mathrm{K}_{\mathrm{i}}-67$ and proliferating cell nuclear antigen is reduced. ${ }^{63}$ Promisingly, corticosteroids appear to primarily inhibit mesenchymal cell proliferation, which may provide benefit by enhancing perisaccular septation. $^{47}$

The impact of antenatal steroids on surfactant production in $\mathrm{CDH}$ is unclear; Davey et $\mathrm{a}^{64}$ demonstrated that antenatal betamethasone partially restored surfactant protein mRNA expression in sheep, whereas Suen et $\mathrm{al}^{51}$ found no effect in the rat. It is also unclear whether antenatal corticosteroids enhance ${ }^{56,65}$ or reduce ${ }^{63}$ the beneficial effects of tracheal occlusion. In current clinical programs, corticosteroids are used due to threatened preterm delivery at around the time of balloon removal (usually at 34 weeks), hence it is often forgotten that they are part of the current clinical prenatal strategy and should be included in experimental models of tracheal occlusion.

\section{Effects on Pulmonary Vasculature in Diaphragmatic Hernia}

Antenatal corticosteroids improve the vasodilation response of pulmonary blood vessels by increasing expression of endothelial nitric oxide synthase and $\mathrm{K}^{+}$channels; ${ }^{53,66}$ however, their effect on vascular proliferation is not yet fully understood. At a biomolecular level, antenatal corticosteroids initially appeared to increase vascular endothelial growth factor (VEGF) receptor expression; ${ }^{52,67}$ however, Gonçalves et al found that in ventilated lungs, dexamethasone was associated with decreased expression of VEGF and its vasodilatory receptor Flk-1. ${ }^{53}$ Morphologically, antenatal corticosteroids increase distal vessel number and decrease distal vessel muscularization. ${ }^{53,56,57}$

\section{Translation from Animal Models to Clinical Practice} At this time, there does not appear to be additional benefit in providing antenatal steroids to $\mathrm{CDH}$ fetuses, other than the well-established benefits of antenatal steroids for infants expected to deliver prior to 34 weeks. ${ }^{9}$ 


\section{Retinoids}

Retinoids are a family of molecules derived from vitamin A, an essential micronutrient required for organogenesis, reproduction, immune competence, cellular differentiation, and vision. The retinoid signaling pathway appears important in normal diaphragmatic and pulmonary development, and it is hypothesized that disruptions in this pathway may contribute to the pathogenesis of $\mathrm{CDH}^{68}$

\section{Pharmacokinetics, Bioavailability, and Mechanism of Action}

Vitamin A is obtained from the diet as retinyl esters in meat or $\beta$-carotene in vegetables, which are then metabolized to retinol in the liver. After being secreted by the liver and transported by retinol binding protein in the blood, retinol enters cells and is eventually converted to the active metabolite, retinoic acid. Retinoic acid enters the nucleus and regulates gene transcription.

In the lungs, retinoid signaling is an important component of lung budding and branching early in development, and later influences septation and alveolarization. ${ }^{69}$

The retinoid signaling pathway also appears to play an important role in complete closure of the diaphragm. Diaphragmatic defects are present in the offspring of vitamin A-deficient rats $^{70}$ and retinoic acid receptor double knockout mice, ${ }^{71}$ and infants with $\mathrm{CDH}$ have low levels of plasma retinol. ${ }^{72,73}$

In the rat model of $\mathrm{CDH}$, the herbicide nitrofen is used to induce diaphragmatic hernia. Noble et $\mathrm{al}^{74}$ suggest that nitrofen acts by inhibiting the enzymes that convert retinol to retinoic acid, whereas Nakazawa et al $^{75}$ suggest that nitrofen interferes with the cellular uptake of retinol. Importantly, both hypotheses indicate that in nitrofen-induced diaphragmatic hernia, administering vitamin A or retinol will not necessarily increase intracellular levels of the active metabolite, retinoic acid. Considering this, retinoic acid appears to be a more appealing therapeutic agent than vitamin $\mathrm{A}$ itself.

Furthermore, while neonatal plasma retinol levels are low in $\mathrm{CDH}$, maternal plasma retinol levels are either equivalent to controls or elevated. ${ }^{72,73}$ This suggests impaired placental transfer of retinoids in the setting of $\mathrm{CDH}$; therefore, vitamin A administered to the mother may never reach the fetus. In contrast, retinoic acid appears to cross the placenta in the nitrofen rat model of $\mathrm{CDH}$, as it exerts a therapeutic effect. ${ }^{76,77}$

\section{Safety}

The use of exogenous retinoids to prevent pulmonary hypoplasia in $\mathrm{CDH}$ requires caution, as retinoid toxicity is associated with teratogenic effects such as spontaneous abortion and cranial neural crest defects. ${ }^{78}$ Rothman et al estimate that among mothers who ingest more than 10,000 IU of vitamin A supplements per day, 1 in 57 infants are born with a birth defect attributable to vitamin A. $^{78}$

The dangers of retinoid teratogenicity are demonstrated by cases in which isotretinoin, used to treat severe acne, has inadvertently been taken during pregnancy. Lammer et $\mathrm{al}^{79}$ determined that of 154 pregnancies exposed to isotretinoin, 95 were aborted electively, 12 spontaneously aborted, and 21 were born with malformations.
Isotretinoin is the 13-cis isomer of retinoic acid and exerts species-dependent teratogenic effects. An extensive body of work undertaken by $\mathrm{Nau}^{80}$ can be summarized as follows. 13-cis-retinoic acid has a long half-life (16 hours) and extensive access to cell nuclei, however, limited placental transfer. Some, but not all, of the teratogenicity of 13-cisretinoic acid can be attributed to its continuous isomerization to all transretinoic acid, which has a short half-life (1 hour) but extensive placental transfer and high affinity for retinoic acid receptors. In humans, exogenous 13-cisretinoic acid is more teratogenic than exogenous all transretinoic acid because continuous isomerization during its long half-life results in higher total fetal exposure to toxic levels of all transretinoic acid.

The teratogenic potency of 13-cis-retinoic acid is more in humans than in rats, likely because the rodent metabolic pathway more efficiently eliminates 13 -cis-retinoic acid and placental transfer is almost nonexistent in rodents. ${ }^{80}$ In rodents, all transretinoic acid is more teratogenic than 13cis-retinoic acid.

Studies in the nitrofen rat have administered all transretinoic acid via intraperitoneal injection at a dose of $5 \mathrm{mg} / \mathrm{kg} /$ $\mathrm{d}$, however, have not reported rates of craniofacial, thymic, or cardiac malformations. ${ }^{76,77}$ Further investigations into potential teratogenicity in the rat, rabbit, and sheep models of $\mathrm{CDH}$ are required before antenatal retinoids should be considered for use in humans.

\section{Effect on the Lungs in Diaphragmatic Hernia}

The effect of retinoids on lung development varies depending on the time of administration. When administered late in lung development (E16-20 in the nitrofen rat; term $=21$ days), antenatal retinoids improved structural maturation without affecting lung growth; the size and number of airspaces were increased (increasing surface area available for gas exchange), distal artery muscularization was decreased, and there was increased expression of VEGF and its receptors, but the lung:body weight ratio was not improved. ${ }^{76,77}$ In contrast, when administered early in lung development (E 9- 14 days in the nitrofen rat), antenatal retinoids improved both lung growth and maturation; the lung:body weight ratio was increased and surfactant protein expression was increased. ${ }^{81,82}$

In the nitrofen rat model, a chemical "first-hit" impairs lung growth early in development. Later, once the diaphragmatic defect has allowed herniation of abdominal viscera, a "second-hit" further impairs pulmonary development. Only the "first-hit" is directly related to nitrofen-related impairment of the retinoid signaling pathway, which explains why only early administration of retinoids improves lung growth. Findings from surgical models of $\mathrm{CDH}$ are consistent with this hypothesis. In the rabbit model, lung growth was unaffected by antenatal retinoids, and in the sheep model, antenatal retinoids were associated with a decreased lung: body weight ratio. ${ }^{83,84}$

While late antenatal retinoids did not improve lung growth, they did appear to improve lung maturation in nitrofen rats. This likely reflects the importance of retinoid signaling in 
septation and alveolarization; thinner interalveolar septa and improved alveolarization were also seen in the sheep model of $\mathrm{CDH}^{84}$ These structural changes were associated with improved lung function after delivery of the lambs. On the contrary, septation and alveolarization were unaffected by antenatal retinoids in the rabbit model of $\mathrm{CDH} .{ }^{83}$

\section{Translation from Animal Models to Clinical Practice}

To improve both lung growth and maturation in the nitrofen rat, antenatal retinoids needed to be administered during the pseudoglandular stage of lung development. ${ }^{85}$ In humans, the pseudoglandular stage is complete by $\sim 18$ weeks. ${ }^{85}$ Given that $\mathrm{CDH}$ is predominantly diagnosed at 20 weeks or later in gestation, ${ }^{86}$ it may not be possible to administer vitamin $A$ at a stage early enough to improve lung:body weight ratio. However, it is sometimes possible to diagnose $\mathrm{CDH}$ in first-trimester screening programs, yet severity assessment has not been validated that early in pregnancy, and the prognosis of these infants is unclear. ${ }^{87}$

Ultimately, vitamin A remains a promising antenatal therapy to improve pulmonary development in $\mathrm{CDH}$ that is worthy of further investigation in animal experiments; however, concerns regarding teratogenicity must be addressed and further advances in early antenatal diagnosis are required before it can be considered in a clinical trial.

\section{Phosphodiesterase-5 Inhibitors}

The previously discussed antenatal medical therapies display limited benefit, may be teratogenic (retinoic acid), or have failed to demonstrate benefit in humans despite promising animal trials (corticosteroids). In contrast, the phosphodiesterase-5 inhibitor sildenafil has been extensively used in animal and human studies for other maternal-fetal conditions, and has demonstrated promising structural and biochemical pulmonary vasculature changes in small animal models of $\mathrm{CDH}^{88-95}$

Sildenafil's extensive use in erectile dysfunction ${ }^{96}$ means that it is now available off-label in a much cheaper generic form. Along with consistent oral bioavailability, ${ }^{97}$ this allows sildenafil to be used in low-resource settings-in stark contrast to the highly specialized care required for other antenatal $\mathrm{CDH}$ interventions such as FETO. ${ }^{30,36}$

Sildenafil is already used clinically in the postnatal management of persistent pulmonary hypertension of the newborn in $\mathrm{CDH}$ neonates, ${ }^{9}$ and has been proven to be safe when given to pregnant women for oligohydramnios, or within trials for growth restriction, however, applying its effects antenatally to improve pulmonary development would be an exciting step forward.

\section{Mechanism of Action}

Phosphodiesterases are a group of enzymes that play an important role in regulating cardiac smooth muscle tone and vascular smooth muscle contraction. ${ }^{98}$ Sildenafil is a relatively selective inhibitor of one of these enzymes, phosphodiesterase-5. By degrading cyclic guanosine monophosphate (cGMP), phosphodiesterase-5 interferes with the nitric oxide-mediated vasodilation process and hence results in vasoconstriction. Sildenafil-induced phosphodiesterase-5 inhibition leads to an increase in the half-life of cGMP, hence vasodilation and increased blood flow (-Fig. 1).

Phosphodiesterase-5 is the most active phosphodiesterase in the pulmonary vasculature, hence sildenafil induces pulmonary vasodilation. ${ }^{99}$ Pulmonary vasodilation reduces pulmonary vascular resistance, which increases pulmonary blood flow. This mechanism of action allows sildenafil to effectively treat pulmonary hypertension in adults ${ }^{100}$ and children, ${ }^{101}$ and there is also early evidence in neonatal populations. ${ }^{102}$ These patients are particularly sensitive to the effects of sildenafil because phosphodiesterase- 5 is upregulated in pulmonary hypertension. ${ }^{99}$

Similarly, phosphodiesterase-5 is upregulated in CDH lungs at birth; ${ }^{103}$ therefore, $\mathrm{CDH}$ infants are often nonresponsive to inhaled nitric oxide. ${ }^{104}$ Sildenafil's acute vasodilatory effect may appear less useful in utero, when gas exchange is not required and pulmonary blood flow is minimal. Yet, in addition to a steady increase in pulmonary blood flow throughout gestation, there are dynamic increases in pulmonary blood flow during accentuated fetal breathing movements. ${ }^{105}$ Sildenafil-mediated vasodilation may therefore enhance these episodes by allowing more blood to flow through the lungs during fetal breathing movements, suggesting a potential role in utero for sildenafil's acute vasodilatory effect.

However, in utero the long-term effects of sildenafil are likely more important. While its effects on pulmonary vascular resistance and pulmonary blood flow are transient, antenatal sildenafil mediates a sustained change in vascular reactivity to birth-related stimuli (such as hyperoxemia) that persists to delivery. ${ }^{106}$ Sildenafil also exerts an antiproliferative effect on pulmonary artery smooth muscle cells, so may reduce the increased distal artery muscularization characteristic of $\mathrm{CDH} .{ }^{107}$ Decreased muscularization may be due to upregulation of antiproliferative bone morphogenetic protein. ${ }^{108}$ Furthermore, phosphodiesterase-5 suppresses VEGF expression, so by inhibiting phosphodiesterase-5, sildenafil may also improve VEGF-driven angiogenesis and therefore restore the reduced number of distal vessels seen in $\mathrm{CDH} .{ }^{109}$ VEGF-driven angiogenesis also creates mature alveolocapillary units ${ }^{110}$ that will appropriately match ventilation and perfusion during neonatal life, reflecting the complex interactions between airway and vascular pulmonary development discussed earlier. ${ }^{111}$

Sildenafil may exert these long-term effects directly, or they may be secondary to increased cGMP levels. ${ }^{107}$ Interestingly, increased cGMP inhibits phosphodiesterase-3 (a cAMP-specific phosphodiesterase) and hence also leads to increased cAMP levels. ${ }^{112}$ cAMP is known to have antiproliferative effects on smooth muscle, which may explain sildenafil's effect on distal arterial musculature. ${ }^{112}$

\section{Pharmacokinetics and Bioavailability}

The impact of antenatal sildenafil on fetuses with $\mathrm{CDH}$ has been predominantly studied in the nitrofen rat model ${ }^{88,89,91-95}$ and also one rabbit study has been published so far (- Table 2). ${ }^{90} \mathrm{An}$ alternative phosphodiesterase-5 inhibitor, tadalafil, has recently been investigated in the sheep model. ${ }^{113}$ 


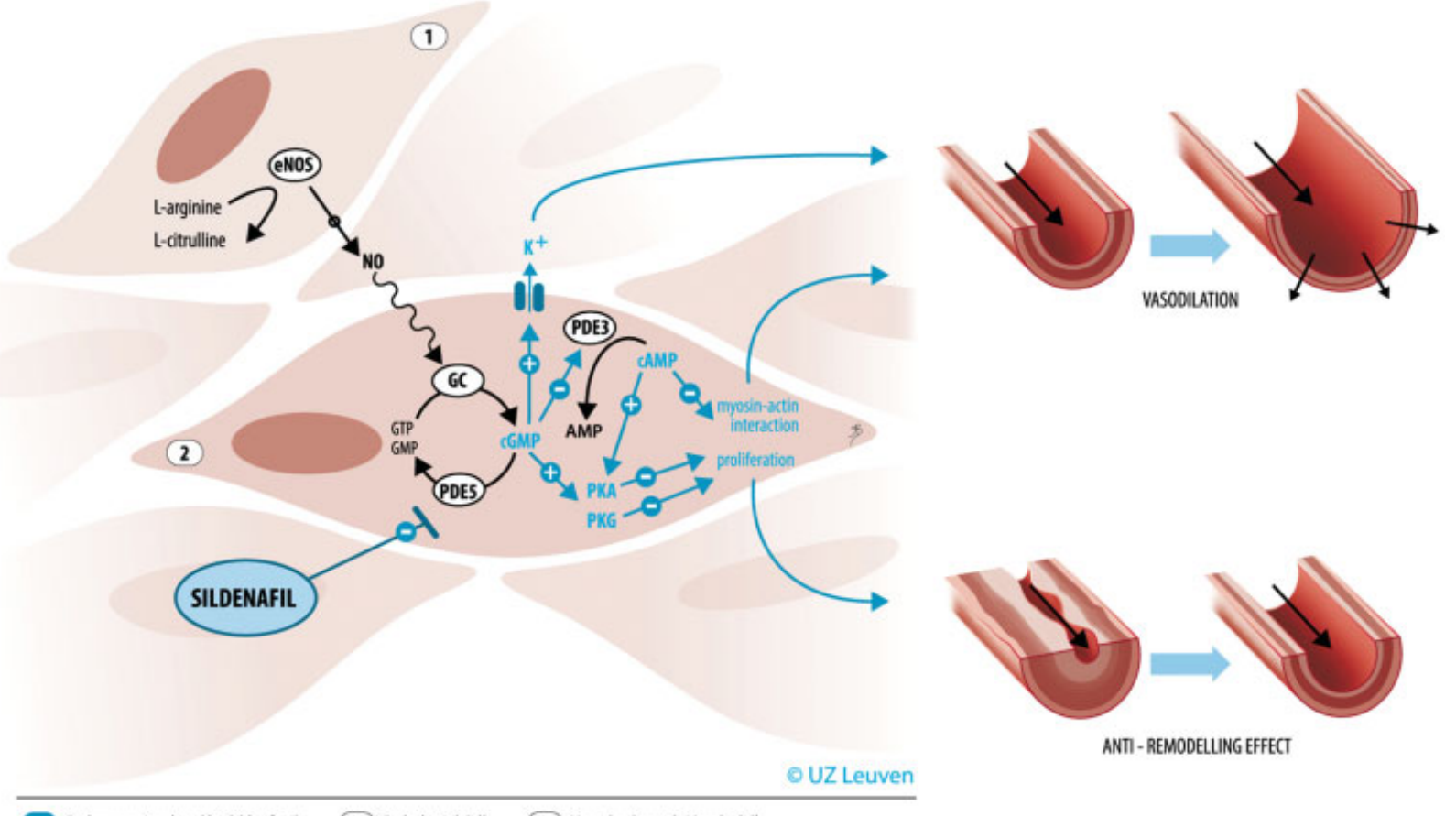

Pathways stimulated by Sildenfanil (1) Endothetial Cell (2) Vascular Smooth Muscle Cell

Fig. 1 Schematic representation of the mechanism of action of sildenafil on the pulmonary vasculature. AMP, adenosine monophosphate; ATP, adenosine triphosphate; cAMP, cyclic AMP; cGMP, cyclic GMP; eNOS, endothelial nitric oxide synthase; GC, guanylate cyclase; GMP, guanosine triphosphate; GTP, guanosine triphosphate; NO, nitric oxide; PDE, phosphodiesterase; PKA, CAMP-dependent protein kinase; PKG, cGMP-dependent protein kinase. (Reproduced with permission from UZ Leuven, Leuven, Belgium. Drawing by Myrthe Boymans.)

Tadalafil is a more potent and selective phosphodiesterase-5 inhibitor; therefore, a lower dose is required to achieve the same effect relative to sildenafil. ${ }^{113}$ Furthermore, its longer half-life means that serum levels would be more consistent with daily oral dosing. Unfortunately, human neonates are unable to properly metabolize tadalafil due to an immature glucuronidation pathway; therefore, it is unlikely to be used clinically as an antenatal therapy. ${ }^{114}$ Nevertheless, when sildenafil treatment was compared with tadalafil in neonates with persistent pulmonary hyperten- sion, both were shown to decrease mean pulmonary artery pressure with no significant difference between the two treatments. ${ }^{115}$

The pharmacokinetics of sildenafil differ between species, mostly due to rate of metabolism. ${ }^{116}$ To obtain plasma levels within the therapeutic range $\left(47-500 \mathrm{ng} / \mathrm{mL}^{90}\right)$, rabbits require $10 \mathrm{mg} / \mathrm{kg} / \mathrm{d}$ and rodents require $100 \mathrm{mg} / \mathrm{kg} / \mathrm{d}$ $\left(-\right.$ Table 2)..$^{90-95}$

In both species, there is excellent bioavailability following both oral and subcutaneous administration, hence either

Table 2 Antenatal sildenafil in experimental models of congenital diaphragmatic hernia

\begin{tabular}{|c|c|c|c|}
\hline Author, y & Dose & Route & Timing \\
\hline \multicolumn{4}{|c|}{ Rat models (gestational term: ED 22) } \\
\hline Luong et al, $2011^{92}$ & $100 \mathrm{mg} / \mathrm{kg} / \mathrm{d}$ Sildenafil & Subcutaneous injection & ED 11.5-20.5 \\
\hline Kattan et al, $2014^{95}$ & $45 \mathrm{mg} / \mathrm{kg}$ BD Sildenafil & Oral & ED 14-22 \\
\hline Lemus-Varela et al, $2014^{91}$ & $100 \mathrm{mg} / \mathrm{kg} / \mathrm{d}$ Sildenafil & Oral & ED 16-20 \\
\hline Yamamoto et al, $2014^{94}$ & $100 \mathrm{mg} / \mathrm{kg} / \mathrm{d}$ Sildenafil & Subcutaneous injection & ED 11.5-20.5 \\
\hline Makanga et al, $2015^{93}$ & $100 \mathrm{mg} / \mathrm{kg} / \mathrm{d}$ Sildenafil & Oral & ED 11-21 \\
\hline Burgos et al, $2016^{88}$ & $100 \mathrm{mg} / \mathrm{kg} / \mathrm{d}$ Sildenafil & Subcutaneous injection & ED 11.5-20.5 \\
\hline Mous et al, $2016^{89}$ & $100 \mathrm{mg} / \mathrm{kg} / \mathrm{d}$ Sildenafil & Oral & ED 17.5-20.5 \\
\hline \multicolumn{4}{|c|}{ Rabbit model (gestational term: GA 31) } \\
\hline Russo et al, $2016^{90}$ & $10 \mathrm{mg} / \mathrm{kg} / \mathrm{d}$ Sildenafil & Subcutaneous injection & GA 24-30 \\
\hline \multicolumn{4}{|c|}{ Sheep model (gestational term: GA 145) } \\
\hline Shue et al, $2014^{113}$ & $2 \mathrm{mg} / \mathrm{kg} / \mathrm{d}$ Tadalafil & Oral & GA 75-135 \\
\hline
\end{tabular}

Abbreviations: ED, embryonic day; GA, days of gestational age. 
method is appropriate. ${ }^{116}$ In the majority of rodent models, sildenafil was administered from the pseudoglandular stage onward; ${ }^{88,91-95}$ however, in the most recent study, sildenafil treatment only began during the more clinically relevant canalicular stage (the stage during which human $\mathrm{CDH}$ is usually detected at $18-20$ weeks ultrasound). ${ }^{89}$ In rabbits, it was administered from the canalicular stage onward. ${ }^{90}$

The first important finding from these studies is that maternal sildenafil successfully crosses the placenta in all current animal models. Interestingly, in sheep, fetal tadalafil concentrations remain at a steady state despite fluctuating maternal levels (- Fig. 2). ${ }^{113}$ This steady state may reflect low fetal metabolism of tadalafil in sheep fetuses, as in human neonates. ${ }^{114}$ These steady fetal concentrations are not seen when sildenafil is used in the rat $^{92}$ and rabbit ${ }^{90}$ models. Sildenafil clearance in human neonates increases threefold (to adult levels) during the first week of postnatal life; ${ }^{117}$ therefore, well-designed fetal pharmacokinetic studies are required to ensure that sildenafil does not accumulate in the fetal circulation when administered antenatally.

It is evident that transplacental sildenafil and tadalafil both exert a biochemical action on the fetal lungs, with an increase in pulmonary cGMP concentration following maternal administration in both the rat and sheep model. ${ }^{92,113}$

\section{Safety}

Human safety data specific to fetuses with CDH are not available for sildenafil, and there have been no adverse effects reported in animal models of $\mathrm{CDH} .{ }^{92}$

In the neonatal population, using sildenafil to treat pulmonary hypertension was not associated with higher rates of any adverse effects in three small randomized controlled trials. ${ }^{118-120}$ On the contrary, a randomized controlled trial investigating sildenafil in the pediatric population found that high-dose sildenafil is associated with greater mortality than low-dose sildenafil. ${ }^{121}$ This association led to the U.S. Food and Drug Administration recommendation against the use of sildenafil in the pediatric population. ${ }^{122}$ However, several expert groups have refuted this recommendation due to limitations of the trial, including inconsistent plasma sildenafil concentrations, no survival data for the placebo group,

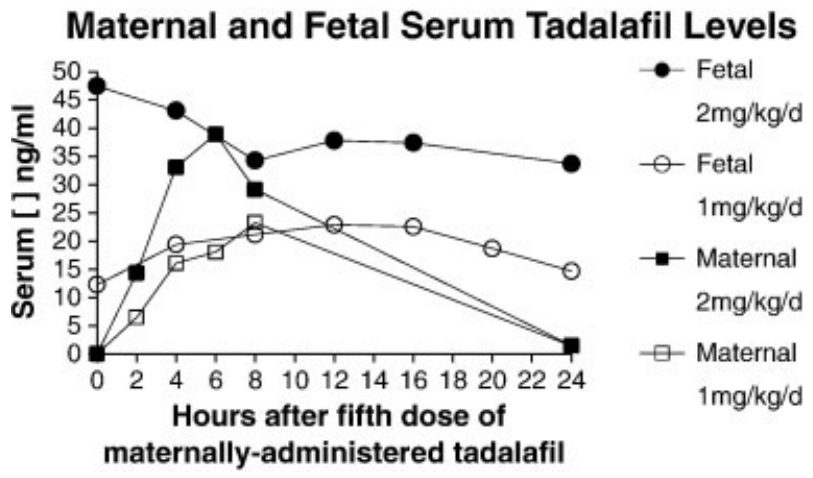

Fig. 2 Maternal and fetal serum tadalafil levels in the sheep model. Tadalafil was given maternally for 5 days, prior to recording data. (Reproduced with permission from Shue et al.) ${ }^{113}$ and a large number of confounding variables. ${ }^{123,124}$ Furthermore, the European Medicines Agency approved sildenafil use in pediatric pulmonary hypertension (while warning against high doses) based on the same evidence. ${ }^{125}$

Antenatally, sildenafil has been investigated in randomized controlled trials to determine its effect upon pregnancy duration in women with preeclampsia, ${ }^{126}$ and on amniotic fluid volume in pregnancies complicated by idiopathic oligohydramnios. ${ }^{127}$ In both trials, no differences in adverse effects between sildenafil and placebo were observed, in either mother or fetus.

Antenatal sildenafil is also under investigation to increase placental blood flow in intrauterine growth restriction (IUGR) in the international STRIDER trial. ${ }^{128}$ A recently published (2016) meta-analysis was unable to draw conclusions about the effect of antenatal sildenafil in IUGR, due to the lack of studies with placebo comparison, ${ }^{129}$ but the ongoing randomized controlled trial has not reported any serious adverse effects to date. ${ }^{128}$ Animal trials have raised controversy over whether sildenafil displays a beneficial ${ }^{130}$ or detrimental ${ }^{131}$ effect on the uteroplacental circulation. Concerns regarding adverse fetal effects have also been raised in an ongoing study in a sheep model of IUGR. ${ }^{132}$ It is important that a safety profile is established in animal models of diaphragmatic hernia before sildenafil is considered for clinical trials in $\mathrm{CDH}$.

\section{Effect on the Lungs in Diaphragmatic Hernia}

Sildenafil appears to be associated with several biomolecular changes, such as supporting a provasodilatory expression profile (- Table 3). ${ }^{92,93,113}$ Sildenafil also restores the vasodilatory response to stimuli such as nitric oxide and oxygen that is impaired in $\mathrm{CDH} .{ }^{92,94}$ Furthermore, increases in bone morphogenic protein signaling (antiproliferative) and Bax/ $\mathrm{Bcl}-2$ ratio (proapoptotic) may underlie a reduction in vessel muscularization. ${ }^{93}$ There is also increased expression of VEGF in the lung parenchyma, which may drive the observed increase in distal vessel number. ${ }^{90}$ Sildenafil has no effect on phosphodiesterase-5 RNA expression but decreases the distribution of phosphodiesterase-5 particularly in distal pulmonary vessels. ${ }^{89}$

Sildenafil improves pulmonary vascular development in experimental models of $\mathrm{CDH}$ by increasing distal vessel number ${ }^{90,92,93,95}$ and decreasing distal vessel muscularization (-Table 4).$^{89-93}$ Sildenafil did not significantly increase total vascular volume; ${ }^{89}$ however, this is less important than the ratio of distal to proximal vessels (as a larger proportion of distal vessels provides greater cross-sectional area, therefore, lower resistance).

A concerning finding is that when sildenafil was given to control animals (i.e., without $\mathrm{CDH}$ ), it decreased the number of distal vessels ${ }^{90,92}$ and decreased total vascular volume. ${ }^{89}$ The authors hypothesized that sildenafil-mediated vasodilation was beneficial in lungs with increased pulmonary vascular resistance, but in normal lungs, hypoperfusion of the pulmonary vascular bed may impair vessel growth. ${ }^{90}$ These findings could alternatively be explained by the fact that while cGMP (increased following sildenafil-induced 
Antenatal Medical Therapies to Improve Lung Development in CDH Kashyap et al.

Table 3 Antenatal sildenafil mediates biomolecular and physiological changes

\begin{tabular}{|l|l|l|l|}
\hline Author, $y$ & Vasodilator expression & Vasoconstrictor expression & Vasoreactivity to vasodilatory stimuli \\
\hline Luong et al, $2011^{92}$ & $\begin{array}{l}\uparrow \text { eNOS } \\
\uparrow \text { VEGF }\end{array}$ & NA & $\uparrow$ Vasodilatory response to NO donor \\
\hline Yamamoto et al, $2014^{94}$ & NA & NA & $\begin{array}{l}\uparrow \text { Vasodilatory response to } \\
\text { maternal hyperoxia }\end{array}$ \\
\hline Makanga et al, $2015^{93}$ & $\begin{array}{l}\uparrow \text { eNOS } \\
\text { iNOS } \\
\uparrow \text { NO }\end{array}$ & $\begin{array}{l}\downarrow \text { ET1 } \\
\downarrow \text { ETA } \\
\downarrow \text { PPET1 }\end{array}$ & NA \\
\hline Burgos et al, $2016^{88}$ & NA & NA & NA \\
\hline Russo et al, $2016^{90}$ & NA & NA & NA \\
\hline Shue et al, $2014^{113}$ & $\uparrow$ eNOS & NA & NA \\
\hline
\end{tabular}

Abbreviations: eNOS, endothelial NO synthase; ET1, endothelin-1; ETA, ET1 receptor A; iNOS, inducible NO synthase; N/A, not applicable; NO, nitric oxide; PBF, pulmonary blood flow; PPET1, ET1 precursor; VEGF, vascular endothelial growth factor.

phosphodiesterase-5 inhibition) is important for vasodilation and angiogenesis, sustained exposure at high levels can lead to lung endothelial cell death and apoptosis. ${ }^{133}$ While sildenafil may attenuate the reduced cGMP levels characteristic of $\mathrm{CDH},{ }^{92}$ its use in healthy fetuses may increase cGMP to toxic levels.

Sildenafil also appears to have some beneficial effects upon airway development (- Table 5). The effect of sildenafil on gross lung size is unclear, with the majority of the evidence showing no difference, ${ }^{90,92,93,113}$ one rat model demonstrating a significant decrease ${ }^{88}$ and two rat models demonstrating a significant increase in lung weight. ${ }^{89,94}$ At a histological level, sildenafil appears to increase distal airway complexity. ${ }^{89,90,93,94}$ On a functional level, rabbit lungs treated with sildenafil demonstrate improved static compliance and total lung capacity. ${ }^{90}$

\section{Translation from Animal Models to Clinical Practice}

Most investigations into antenatal sildenafil in $\mathrm{CDH}$ have been performed in the nitrofen rat model, which does not allow assessment of the physiological transition at birth. Ultrasound assessments suggest that sildenafil reduces pulsatility index, an indicator of pulmonary vascular resistance. ${ }^{88,90}$ In the larger sheep model, it was possible to demonstrate that tadalafil improved pulmonary blood flow during neonatal ventilation. ${ }^{113}$ Despite no significant difference observed in mean pulmonary artery pressure, tadalafil did appear to improve pulmonary artery pressure response

Table 4 Antenatal sildenafil mediates changes in vascular morphology

\begin{tabular}{|c|c|c|c|}
\hline Author, y & $\begin{array}{l}\text { Vessel number } \\
\text { (distal vessel number } \\
\text { or density) }\end{array}$ & $\begin{array}{l}\text { Vessel muscularization } \\
\text { (medial wall thickness) }\end{array}$ & Other \\
\hline \multicolumn{4}{|l|}{ Rat models (sildenafil) } \\
\hline Luong et al, $2011^{92}$ & $\begin{array}{l}\text { In } \mathrm{CDH}: \uparrow \\
\text { In non-CDH: } \downarrow\end{array}$ & $\downarrow$ & $\begin{array}{l}\downarrow \text { Right ventricular } \\
\text { hypertrophy }\end{array}$ \\
\hline Kattan et al, $2014^{95}$ & $\uparrow$ & $\begin{array}{l}\text { Proximal vessels: } \uparrow \\
\text { Distal vessels: - }\end{array}$ & NA \\
\hline Lemus-Varela et al, $2014^{91}$ & NA & $\downarrow$ & NA \\
\hline Makanga et al, $2015^{93}$ & $\bar{\uparrow}$ & $\downarrow$ & $\uparrow$ Vessel diameter \\
\hline Burgos et al, $2016^{88}$ & $\mathrm{NA}$ & No effect & NA \\
\hline Mous et al, $2016^{89}$ & NA & $\downarrow$ & $\begin{array}{l}\downarrow \text { Cellular markers of } \\
\text { muscularization }\end{array}$ \\
\hline \multicolumn{4}{|l|}{ Rabbit model (sildenafil) } \\
\hline Russo et al, $2016^{90}$ & $\begin{array}{l}\text { In } \mathrm{CDH}: \uparrow \\
\text { In non-CDH: } \downarrow\end{array}$ & $\downarrow$ & NA \\
\hline \multicolumn{4}{|l|}{ Sheep model (tadalafil) } \\
\hline Shue et al, $2014^{113}$ & NA & NA & $\begin{array}{l}\text { No effect on right } \\
\text { ventricular hypertrophy }\end{array}$ \\
\hline
\end{tabular}

Abbreviations: $\mathrm{CDH}$, congenital diaphragmatic hernia; N/A, not applicable. 
Antenatal Medical Therapies to Improve Lung Development in CDH Kashyap et al.

Table 5 Antenatal sildenafil mediates changes in airway histology and function

\begin{tabular}{|c|c|c|c|c|}
\hline Author, y & Gross lung size & Septal thickness & Airway complexity & Functional \\
\hline \multicolumn{5}{|l|}{ Rat models (sildenafil) } \\
\hline Luong et al, $2011^{92}$ & No effect & $\downarrow$ & NA & NA \\
\hline $\begin{array}{l}\text { Lemus-Varela et al, } \\
2014^{91}\end{array}$ & NA & No effect & No effect & NA \\
\hline Yamamoto et al, $2014^{94}$ & $\uparrow$ LBWR & NA & $\uparrow$ Radial saccular count & NA \\
\hline Makanga et al, $2015^{93}$ & No effect & No effect & $\uparrow$ Radial alveolar count & NA \\
\hline Burgos et al, $2016^{88}$ & $\downarrow$ LBWR & $\downarrow$ & $\begin{array}{l}\uparrow \text { Alveolar volume } \\
\text { density } \\
\text { No effect on radial } \\
\text { alveolar count }\end{array}$ & $\begin{array}{l}\uparrow \mathrm{PO}_{2} \\
\text { No effect on tidal volume }\end{array}$ \\
\hline Mous et al, $2016^{89}$ & $\uparrow$ LKWR & No effect & $\begin{array}{l}\uparrow \text { Alveolar airspace } \\
\text { diameter }\end{array}$ & NA \\
\hline \multicolumn{5}{|l|}{ Rabbit model (sildenafil) } \\
\hline Russo et al, $2016^{90}$ & No effect & No effect & $\begin{array}{l}\uparrow \text { Distal airway } \\
\text { complexity }\end{array}$ & $\begin{array}{l}\uparrow \text { Static compliance } \\
\uparrow \text { Total lung capacity }\end{array}$ \\
\hline \multicolumn{5}{|l|}{ Sheep model (tadalafil) } \\
\hline Shue et al, $2014^{113}$ & No effect & NA & NA & NA \\
\hline
\end{tabular}

Abbreviations: LBWR, lung-to-body weight ratio; LKWR, lung-to-kidney weight ratio (used because body weight was significantly different between groups in this study); $\mathrm{NA}$, not applicable; $\mathrm{PO}_{2}$, partial pressure of oxygen (from a mixed arteriovenous sample).

to inhaled nitric oxide. ${ }^{113}$ Further experiments should be conducted in the sheep model to verify these results, and assess their relevance to sildenafil. Meanwhile, we are preparing to move to clinical trials and have recently obtained orphan designation for antenatal sildenafil for $\mathrm{CDH}$ by the European Medicines Agency.

\section{Future Directions}

Although FETO is limited by complications associated with preterm delivery and technical difficulties, it does significantly improve lung growth and may be associated with a significant decrease in morbidity and mortality in $\mathrm{CDH} .{ }^{12,28}$ To overcome the limitations while retaining the benefits of FETO, antenatal medical therapies should be investigated not only as alternatives to tracheal occlusion but also for potential synergistic effects. Mixed results from animal experiments make it unclear whether betamethasone and vitamin A have synergistic effects with tracheal occlusion; $; 4,134-136$ however, promising early results from a rabbit model of $\mathrm{CDH}$ indicate that there may be synergistic effects of antenatal sildenafil and tracheal occlusion on vascular and parenchymal lung development. ${ }^{137}$ FETO improves lung growth and sildenafil appears to improve pulmonary vascular development, so further investigating synergistic effects between the two is an important avenue for future research.

\section{Conclusion}

Novel approaches to $\mathrm{CDH}$ management are urgently required to further reduce the significant mortality associated with severe CDH because postnatal management occurs too late to prevent lung hypoplasia and pulmonary hypertension. Antenatal surgical approaches are limited by high rates of preterm birth and high technical complexity limiting availability. Of the currently investigated antenatal medical therapies for $\mathrm{CDH}$, the phosphodiesterase-5 inhibitor sildenafil appears the most promising candidate for a future clinical trial. Small animal studies have demonstrated that antenatal sildenafil attenuates vascular remodeling in utero; ${ }^{90-95}$ however, further research is required to determine if this leads to a functional improvement during the neonatal cardiovascular transition. We are hopeful that one day a novel antenatal medical therapy such as sildenafil will offer a new treatment modality in the care of pregnancies with severe $\mathrm{CDH}$.

\section{References}

1 Kotecha S, Barbato A, Bush A, et al. Congenital diaphragmatic hernia. Eur Respir J 2012;39(04):820-829

2 Harding R, Hooper SB. Regulation of lung expansion and lung growth before birth. J Appl Physiol (1985) 1996;81(01):209-224

3 Moessinger AC, Harding R, Adamson TM, Singh M, Kiu GT. Role of lung fluid volume in growth and maturation of the fetal sheep lung. J Clin Invest 1990;86(04):1270-1277

4 Harding R, Hooper SB, Han VK. Abolition of fetal breathing movements by spinal cord transection leads to reductions in fetal lung liquid volume, lung growth, and IGF-II gene expression. Pediatr Res 1993;34(02):148-153

5 Miller AA, Hooper SB, Harding R. Role of fetal breathing movements in control of fetal lung distension. J Appl Physiol (1985) 1993;75(06):2711-2717

6 Stenmark KR, Abman SH. Lung vascular development: implications for the pathogenesis of bronchopulmonary dysplasia. Annu Rev Physiol 2005;67:623-661

7 Keller RL. Antenatal and postnatal lung and vascular anatomic and functional studies in congenital diaphragmatic hernia: 
implications for clinical management. Am J Med Genet C Semin Med Genet 2007;145C(02):184-200

8 Dillon PW, Cilley RE, Mauger D, Zachary C, Meier A. The relationship of pulmonary artery pressure and survival in congenital diaphragmatic hernia. J Pediatr Surg 2004;39(03):307-312

9 Snoek KG, Reiss IK, Greenough A, et al; CDH EURO Consortium. Standardized Postnatal Management of Infants with Congenital Diaphragmatic Hernia in Europe: The CDH EURO Consortium Consensus - 2015 Update. Neonatology 2016;110(01):66-74

10 Wynn J, Krishnan U, Aspelund G, et al. Outcomes of congenital diaphragmatic hernia in the modern era of management. J Pediatr 2013;163(01):114-9.e1

11 Danzer E, Hedrick HL. Controversies in the management of severe congenital diaphragmatic hernia. Semin Fetal Neonatal Med 2014;19(06):376-384

12 Jani JC, Nicolaides KH, Gratacós E, et al. Severe diaphragmatic hernia treated by fetal endoscopic tracheal occlusion. Ultrasound Obstet Gynecol 2009;34(03):304-310

13 Pereira-Terra P, Deprest JA, Kholdebarin R, et al. Unique tracheal fluid microRNA signature predicts response to FETO in patients with congenital diaphragmatic hernia. Ann Surg 2015;262(06): $1130-1140$

14 Eastwood MP, Russo FM, Toelen J, Deprest J. Medical interventions to reverse pulmonary hypoplasia in the animal model of congenital diaphragmatic hernia: a systematic review. Pediatr Pulmonol 2015;50(08):820-838

15 Greer JJ. Current concepts on the pathogenesis and etiology of congenital diaphragmatic hernia. Respir Physiol Neurobiol 2013; 189(02):232-240

16 Puri P, Wester T. Historical aspects of congenital diaphragmatic hernia. Pediatr Surg Int 1997;12(02):95-100

17 Keijzer R, Liu J, Deimling J, Tibboel D, Post M. Dual-hit hypothesis explains pulmonary hypoplasia in the nitrofen model of congenital diaphragmatic hernia. Am J Pathol 2000;156(04): 1299-1306

18 Zussman ME, Bagby M, Benson DW, Gupta R, Hirsch R. Pulmonary vascular resistance in repaired congenital diaphragmatic hernia vs. age-matched controls. Pediatr Res 2012;71(06):697-700

19 Flemmer AW, Thio M, Wallace MJ, et al. Lung hypoplasia in newborn rabbits with a diaphragmatic hernia affects pulmonary ventilation but not perfusion. Pediatr Res 2017;82(03):536-543

20 Hooper SB, Polglase GR, te Pas AB. A physiological approach to the timing of umbilical cord clamping at birth. Arch Dis Child Fetal Neonatal Ed 2015;100(04):F355-F360

21 Mohseni-Bod H, Bohn D. Pulmonary hypertension in congenital diaphragmatic hernia. Semin Pediatr Surg 2007;16(02):126-133

22 Geggel RL, Murphy JD, Langleben D, Crone RK, Vacanti JP, Reid LM. Congenital diaphragmatic hernia: arterial structural changes and persistent pulmonary hypertension after surgical repair. J Pediatr 1985;107(03):457-464

23 Carmel JA, Friedman F, Adams FH. Fetal tracheal ligation and lung development. Am J Dis Child 1965;109:452-456

24 Flake AW, Crombleholme TM, Johnson MP, Howell LJ, Adzick NS. Treatment of severe congenital diaphragmatic hernia by fetal tracheal occlusion: clinical experience with fifteen cases. Am J Obstet Gynecol 2000;183(05):1059-1066

25 Deprest J, Gratacos E, Nicolaides KH; FETO Task Group. Fetoscopic tracheal occlusion (FETO) for severe congenital diaphragmatic hernia: evolution of a technique and preliminary results. Ultrasound Obstet Gynecol 2004;24(02):121-126

26 Harrison MR, Keller RL, Hawgood SB, et al. A randomized trial of fetal endoscopic tracheal occlusion for severe fetal congenital diaphragmatic hernia. N Engl J Med 2003;349(20):1916-1924

27 Deprest JA, Nicolaides K, Gratacos E. Fetal surgery for congenital diaphragmatic hernia is back from never gone. Fetal Diagn Ther 2011;29(01):6-17

28 Al-Maary J, Eastwood MP, Russo FM, Deprest JA, Keijzer R. Fetal tracheal occlusion for severe pulmonary hypoplasia in isolated congenital diaphragmatic hernia: a systematic review and metaanalysis of survival. Ann Surg 2016;264(06):929-933

29 Dekoninck P, Gratacos E, Van Mieghem T, et al. Results of fetal endoscopic tracheal occlusion for congenital diaphragmatic hernia and the set up of the randomized controlled TOTAL trial. Early Hum Dev 2011;87(09):619-624

30 Deprest J, Brady P, Nicolaides K, et al. Prenatal management of the fetus with isolated congenital diaphragmatic hernia in the era of the TOTAL trial. Semin Fetal Neonatal Med 2014;19(06): 338-348

31 Flageole H, Evrard VA, Piedboeuf B, Laberge J-M, Lerut TE, Deprest JA. The plug-unplug sequence: an important step to achieve type II pneumocyte maturation in the fetal lamb model. J Pediatr Surg 1998;33(02):299-303

32 Flecknoe SJ, Wallace MJ, Harding R, Hooper SB. Determination of alveolar epithelial cell phenotypes in fetal sheep: evidence for the involvement of basal lung expansion. J Physiol 2002;542 (Pt 1):245-253

33 Lines A, Gillett AM, Phillips ID, Wallace MJ, Hooper SB. Reexpression of pulmonary surfactant proteins following tracheal obstruction in fetal sheep. Exp Physiol 2001;86(01):55-63

34 Deprest J, Nicolaides K, Done' E, et al. Technical aspects of fetal endoscopic tracheal occlusion for congenital diaphragmatic hernia. J Pediatr Surg 2011;46(01):22-32

35 Jiménez JA, Eixarch E, DeKoninck P, et al. Balloon removal after fetoscopic endoluminal tracheal occlusion for congenital diaphragmatic hernia. Am J Obstet Gynecol 2017;217(01):78. e1-78.e11

36 Wegrzyn P, Weigl W, Szymusik I, et al. Premature labor after fetal endoscopic tracheal occlusion for congenital diaphragmatic hernia: post-procedure management problems. Ultrasound Obstet Gynecol 2010;36(01):124-125

37 Nardo L, Hooper SB, Harding R. Stimulation of lung growth by tracheal obstruction in fetal sheep: relation to luminal pressure and lung liquid volume. Pediatr Res 1998;43(02):184-190

38 Pederiva F, Ghionzoli M, Pierro A, De Coppi P, Tovar JA. Amniotic fluid stem cells rescue both in vitro and in vivo growth, innervation, and motility in nitrofen-exposed hypoplastic rat lungs through paracrine effects. Cell Transplant 2013;22(09):1683-1694

39 Yuniartha R, Alatas FS, Nagata K, et al. Therapeutic potential of mesenchymal stem cell transplantation in a nitrofen-induced congenital diaphragmatic hernia rat model. Pediatr Surg Int 2014;30(09):907-914

40 DeKoninck P, Toelen J, Roubliova X, et al. The use of human amniotic fluid stem cells as an adjunct to promote pulmonary development in a rabbit model for congenital diaphragmatic hernia. Prenat Diagn 2015;35(09):833-840

41 Hodges RJ, Lim R, Jenkin G, Wallace EM. Amnion epithelial cells as a candidate therapy for acute and chronic lung injury. Stem Cells Int 2012;2012:709763

42 De Coppi P, Deprest J. Regenerative medicine solutions in congenital diaphragmatic hernia. Semin Pediatr Surg 2017;26(03): 171-177

43 Lally KP, Bagolan P, Hosie S, et al; Congenital Diaphragmatic Hernia Study Group. Corticosteroids for fetuses with congenital diaphragmatic hernia: can we show benefit? J Pediatr Surg 2006; 41(04):668-674, discussion 668-674

44 Liggins GC, Howie RN. A controlled trial of antepartum glucocorticoid treatment for prevention of the respiratory distress syndrome in premature infants. Pediatrics 1972;50(04):515-525

45 Ballard PL, Ballard RA. Scientific basis and therapeutic regimens for use of antenatal glucocorticoids. Am J Obstet Gynecol 1995; 173(01):254-262

46 Whitsett JA, Matsuzaki Y. Transcriptional regulation of perinatal lung maturation. Pediatr Clin North Am 2006;53(05):873-887

47 Bird AD, Tan KH, Olsson PF, et al. Identification of glucocorticoidregulated genes that control cell proliferation during murine respiratory development. J Physiol 2007;585(Pt 1):187-201 
48 Cole TJ, Solomon NM, Van Driel R, et al. Altered epithelial cell proportions in the fetal lung of glucocorticoid receptor null mice. Am J Respir Cell Mol Biol 2004;30(05):613-619

49 Kemp MW, Newnham JP, Challis JG, Jobe AH, Stock SJ. The clinical use of corticosteroids in pregnancy. Hum Reprod Update 2016; 22(02):240-259

50 George DK, Cooney TP, Chiu BK, Thurlbeck WM. Hypoplasia and immaturity of the terminal lung unit (acinus) in congenital diaphragmatic hernia. Am Rev Respir Dis 1987;136(04):947-950

51 Suen HC, Bloch KD, Donahoe PK. Antenatal glucocorticoid corrects pulmonary immaturity in experimentally induced congenital diaphragmatic hernia in rats. Pediatr Res 1994;35(05): 523-529

52 Schmidt AF, Gonçalves FL, Nassr AC, Pereira LA, Farmer D, Sbragia L. Antenatal steroid and tracheal occlusion restore vascular endothelial growth factor receptors in congenital diaphragmatic hernia rat model. Am J Obstet Gynecol 2010;203(02):184. e13-184.e20

53 Gonçalves FL, Figueira RL, Simões AL, et al. Effect of corticosteroids and lung ventilation in the VEGF and NO pathways in congenital diaphragmatic hernia in rats. Pediatr Surg Int 2014; 30(12):1207-1215

54 Oue T, Shima H, Taira Y, Puri P. Administration of antenatal glucocorticoids upregulates peptide growth factor gene expression in nitrofen-induced congenital diaphragmatic hernia in rats. J Pediatr Surg 2000;35(01):109-112

55 Tannuri U, Rodrigues CJ, Maksoud-Filho JG, Santos MM, Tannuri AC, Rodrigues AJ Jr. The effects of prenatal intraamniotic surfactant or dexamethasone administration on lung development are comparable to changes induced by tracheal ligation in an animal model of congenital diaphragmatic hernia: studies of lung glycogen content, elastic fiber density, and collagen content. J Pediatr Surg 1998;33(12):1776-1783

56 Roubliova XI, Lewi PJ, Verbeken EK, et al. The effect of maternal betamethasone and fetal tracheal occlusion on pulmonary vascular morphometry in fetal rabbits with surgically induced diaphragmatic hernia: a placebo controlled morphologic study. Prenat Diagn 2009;29(07):674-681

57 Rodrigues CJ, Tannuri U, Tannuri AC, Maksoud-Filho J, Rodrigues AJ Jr. Prenatal tracheal ligation or intra-amniotic administration of surfactant or dexamethasone prevents some structural changes in the pulmonary arteries of surgically created diaphragmatic hernia in rabbits. Rev Hosp Clin Fac Med Sao Paulo 2002;57(01):1-8

58 Hedrick HL, Kaban JM, Pacheco BA, et al. Prenatal glucocorticoids improve pulmonary morphometrics in fetal sheep with congenital diaphragmatic hernia. J Pediatr Surg 1997;32(02):217-221

59 Schnitzer JJ, Hedrick HL, Pacheco BA, et al. Prenatal glucocorticoid therapy reverses pulmonary immaturity in congenital diaphragmatic hernia in fetal sheep. Ann Surg 1996;224(04): 430-437, discussion 437-439

60 National Institute of Health. Effect of corticosteroids for fetal maturation on perinatal outcomes. NIH Consens Statement 1994;12(02):1-24

61 Roberts D, Brown J, Medley N, Dalziel SR. Antenatal corticosteroids for accelerating fetal lung maturation for women at risk of preterm birth. Cochrane Database Syst Rev 2017;3:CD004454

62 Wapner RJ, Sorokin Y, Mele L, et al; National Institute of Child Health and Human Development Maternal-Fetal Medicine Units Network. Long-term outcomes after repeat doses of antenatal corticosteroids. N Engl J Med 2007;357(12):1190-1198

63 Mayer S, Klaritsch P, Sbragia L, Toelen J, Till H, Deprest JA. Maternal administration of betamethasone inhibits proliferation induced by fetal tracheal occlusion in the nitrofen rat model for congenital diaphragmatic hernia: a placebo-controlled study. Pediatr Surg Int 2008;24(12):1287-1295

64 Davey MG, Danzer E, Schwarz U, et al. Prenatal glucocorticoids improve lung morphology and partially restores surfactant
mRNA expression in lambs with diaphragmatic hernia undergoing fetal tracheal occlusion. Pediatr Pulmonol 2006;41(12): 1188-1196

65 Boland RE, Nardo L, Hooper SB. Cortisol pretreatment enhances the lung growth response to tracheal obstruction in fetal sheep. Am J Physiol 1997;273(6 Pt 1):L1126-L1131

66 Sakai M, Unemoto K, Solari V, Puri P. Decreased expression of voltage-gated $\mathrm{K}+$ channels in pulmonary artery smooth muscles cells in nitrofen-induced congenital diaphragmatic hernia in rats. Pediatr Surg Int 2004;20(03):192-196

67 Roubliova XI, Lewi PJ, Vaast P, et al. Effects of betamethasone on peripheral arterial development in term fetal rabbit. Pediatr Pulmonol 2008;43(08):795-805

68 Coste K, Beurskens LW, Blanc P, et al. Metabolic disturbances of the vitamin A pathway in human diaphragmatic hernia. Am J Physiol Lung Cell Mol Physiol 2015;308(02):L147-L157

69 Montedonico S, Nakazawa N, Puri P. Congenital diaphragmatic hernia and retinoids: searching for an etiology. Pediatr Surg Int 2008;24(07):755-761

70 Wilson JG, Roth CB, Warkany J. An analysis of the syndrome of malformations induced by maternal vitamin A deficiency. Effects of restoration of vitamin $A$ at various times during gestation. Am J Anat 1953;92(02):189-217

71 Mendelsohn C, Lohnes D, Décimo D, et al. Function of the retinoic acid receptors (RARs) during development (II). Multiple abnormalities at various stages of organogenesis in RAR double mutants. Development 1994;120(10):2749-2771

72 Major D, Cadenas M, Fournier L, Leclerc S, Lefebvre M, Cloutier R. Retinol status of newborn infants with congenital diaphragmatic hernia. Pediatr Surg Int 1998;13(08):547-549

73 Beurskens LW, Tibboel D, Lindemans J, et al. Retinol status of newborn infants is associated with congenital diaphragmatic hernia. Pediatrics 2010;126(04):712-720

74 Noble BR, Babiuk RP, Clugston RD, et al. Mechanisms of action of the congenital diaphragmatic hernia-inducing teratogen nitrofen. Am J Physiol Lung Cell Mol Physiol 2007;293(04): L1079-L1087

75 Nakazawa N, Takayasu H, Montedonico S, Puri P. Altered regulation of retinoic acid synthesis in nitrofen-induced hypoplastic lung. Pediatr Surg Int 2007;23(05):391-396

76 Schmidt AF, Gonçalves FL, Regis AC, Gallindo RM, Sbragia L. Prenatal retinoic acid improves lung vascularization and VEGF expression in CDH rat. Am J Obstet Gynecol 2012;207(01):76. e25-76.e32

77 Montedonico S, Sugimoto K, Felle P, Bannigan J, Puri P. Prenatal treatment with retinoic acid promotes pulmonary alveologenesis in the nitrofen model of congenital diaphragmatic hernia. J Pediatr Surg 2008;43(03):500-507

78 Rothman KJ, Moore LL, Singer MR, Nguyen U-SDT, Mannino S, Milunsky A. Teratogenicity of high vitamin A intake. N Engl J Med 1995;333(21):1369-1373

79 Lammer EJ, Chen DT, Hoar RM, et al. Retinoic acid embryopathy. N Engl J Med 1985;313(14):837-841

$80 \mathrm{Nau} \mathrm{H}$. Teratogenicity of isotretinoin revisited: species variation and the role of all-trans-retinoic acid. J Am Acad Dermatol 2001; 45(05):S183-S187

81 Baptista MJ, Melo-Rocha G, Pedrosa C, et al. Antenatal vitamin A administration attenuates lung hypoplasia by interfering with early instead of late determinants of lung underdevelopment in congenital diaphragmatic hernia. J Pediatr Surg 2005;40(04): 658-665

82 Thébaud B, Barlier-Mur AM, Chailley-Heu B, et al. Restoring effects of vitamin $A$ on surfactant synthesis in nitrofen-induced congenital diaphragmatic hernia in rats. Am J Respir Crit Care Med 2001;164(06):1083-1089

83 Gallot D, Coste K, Jani J, et al. Effects of maternal retinoic acid administration in a congenital diaphragmatic hernia rabbit model. Pediatr Pulmonol 2008;43(06):594-603 
84 Lewis NA, Holm BA, Rossman J, Swartz D, Glick PL. Late administration of antenatal vitamin A promotes pulmonary structural maturation and improves ventilation in the lamb model of congenital diaphragmatic hernia. Pediatr Surg Int 2011;27 (02):119-124

85 Pringle KC. Human fetal lung development and related animal models. Clin Obstet Gynecol 1986;29(03):502-513

86 Garne E, Haeusler M, Barisic I, Gjergja R, Stoll C, Clementi M; Euroscan Study Group. Congenital diaphragmatic hernia: evaluation of prenatal diagnosis in 20 European regions. Ultrasound Obstet Gynecol 2002;19(04):329-333

87 Sebire NJ, Snijders RJ, Davenport M, Greenough A, Nicolaides KH. Fetal nuchal translucency thickness at 10-14 weeks' gestation and congenital diaphragmatic hernia. Obstet Gynecol 1997;90 (06):943-946

88 Burgos CM, Pearson EG, Davey M, et al. Improved pulmonary function in the nitrofen model of congenital diaphragmatic hernia following prenatal maternal dexamethasone and/or sildenafil. Pediatr Res 2016;80(04):577-585

89 Mous DS, Kool HM, Buscop-van Kempen MJ, et al. Clinically relevant timing of antenatal sildenafil treatment reduces pulmonary vascular remodeling in congenital diaphragmatic hernia. Am J Physiol Lung Cell Mol Physiol 2016;311(04):L734-L742

90 Russo FM, Toelen J, Eastwood MP, et al. Transplacental sildenafil rescues lung abnormalities in the rabbit model of diaphragmatic hernia. Thorax 2016;71(06):517-525

91 Lemus-Varela MdeL, Soliz A, Gómez-Meda BC, et al. Antenatal use of bosentan and/or sildenafil attenuates pulmonary features in rats with congenital diaphragmatic hernia. World J Pediatr 2014;10(04):354-359

92 Luong C, Rey-Perra J, Vadivel A, et al. Antenatal sildenafil treatment attenuates pulmonary hypertension in experimental congenital diaphragmatic hernia. Circulation 2011;123(19):2120-2131

93 Makanga M, Maruyama H, Dewachter C, et al. Prevention of pulmonary hypoplasia and pulmonary vascular remodeling by antenatal simvastatin treatment in nitrofen-induced congenital diaphragmatic hernia. Am J Physiol Lung Cell Mol Physiol 2015; 308(07):L672-L682

94 Yamamoto Y, Thebaud B, Vadivel A, Eaton F, Jain V, Hornberger LK. Doppler parameters of fetal lung hypoplasia and impact of sildenafil. Am J Obstet Gynecol 2014;211(03):263.e1-263.e8

95 Kattan J, Céspedes C, González A, Vio CP. Sildenafil stimulates and dexamethasone inhibits pulmonary vascular development in congenital diaphragmatic hernia rat lungs. Neonatology 2014; 106(01):74-80

96 Fink HA, Mac Donald R, Rutks IR, Nelson DB, Wilt TJ. Sildenafil for male erectile dysfunction: a systematic review and meta-analysis. Arch Intern Med 2002;162(12):1349-1360

97 Nichols DJ, Muirhead GJ, Harness JA. Pharmacokinetics of sildenafil after single oral doses in healthy male subjects: absolute bioavailability, food effects and dose proportionality. Br J Clin Pharmacol 2002;53(Suppl 1):5S-12S

98 Kass DA, Takimoto E, Nagayama T, Champion HC. Phosphodiesterase regulation of nitric oxide signaling. Cardiovasc Res 2007; 75(02):303-314

99 Corbin JD, Beasley A, Blount MA, Francis SH. High lung PDE5: a strong basis for treating pulmonary hypertension with PDE5 inhibitors. Biochem Biophys Res Commun 2005;334(03):930-938

100 Galiè N, Ghofrani HA, Torbicki A, et al; Sildenafil Use in Pulmonary Arterial Hypertension (SUPER) Study Group. Sildenafil citrate therapy for pulmonary arterial hypertension. $\mathrm{N}$ Engl J Med 2005;353(20):2148-2157

101 Barst RJ, Ivy DD, Gaitan G, et al. A randomized, double-blind, placebo-controlled, dose-ranging study of oral sildenafil citrate in treatment-naive children with pulmonary arterial hypertension. Circulation 2012;125(02):324-334

102 Shah PS, Ohlsson A. Sildenafil for pulmonary hypertension in neonates. Cochrane Database Syst Rev 2011;(08):CD005494
103 Vukcevic Z, Coppola CP, Hults C, Gosche JR. Nitrovasodilator responses in pulmonary arterioles from rats with nitrofeninduced congenital diaphragmatic hernia. J Pediatr Surg 2005; 40(11):1706-1711

104 Travadi JN, Patole SK. Phosphodiesterase inhibitors for persistent pulmonary hypertension of the newborn: a review. Pediatr Pulmonol 2003;36(06):529-535

105 Polglase GR, Wallace MJ, Grant DA, Hooper SB. Influence of fetal breathing movements on pulmonary hemodynamics in fetal sheep. Pediatr Res 2004;56(06):932-938

106 Jaillard S, Larrue B, Deruelle P, et al. Effects of phosphodiesterase 5 inhibitor on pulmonary vascular reactivity in the fetal lamb. Ann Thorac Surg 2006;81(03):935-942

107 Tantini B, Manes A, Fiumana E, et al. Antiproliferative effect of sildenafil on human pulmonary artery smooth muscle cells. Basic Res Cardiol 2005;100(02):131-138

108 Yang J, Li X, Al-Lamki RS, et al. Sildenafil potentiates bone morphogenetic protein signaling in pulmonary arterial smooth muscle cells and in experimental pulmonary hypertension. Arterioscler Thromb Vasc Biol 2013;33(01):34-42

109 Ladha F, Bonnet S, Eaton F, Hashimoto K, Korbutt G, Thébaud B. Sildenafil improves alveolar growth and pulmonary hypertension in hyperoxia-induced lung injury. Am J Respir Crit Care Med 2005;172(06):750-756

110 Park HS, Park JW, Kim HJ, et al. Sildenafil alleviates bronchopulmonary dysplasia in neonatal rats by activating the hypoxiainducible factor signaling pathway. Am J Respir Cell Mol Biol 2013;48(01):105-113

111 Aman J, Bogaard HJ, Vonk Noordegraaf A. Why vessels do matter in pulmonary disease. Thorax 2016;71(08):767-769

112 Koyama H, Bornfeldt KE, Fukumoto S, Nishizawa Y. Molecular pathways of cyclic nucleotide-induced inhibition of arterial smooth muscle cell proliferation. J Cell Physiol 2001;186(01):1-10

113 Shue EH, Schecter SC, Gong W, et al. Antenatal maternallyadministered phosphodiesterase type 5 inhibitors normalize eNOS expression in the fetal lamb model of congenital diaphragmatic hernia. J Pediatr Surg 2014;49(01):39-45, discussion 45

114 Vorhies EE, Ivy DD. Drug treatment of pulmonary hypertension in children. Paediatr Drugs 2014;16(01):43-65

115 Alipour MR, Lookzadeh MH, Namayandeh SM, Pezeshkpour Z, Sarebanhassanabadi M. Comparison of tadalafil and sildenafil in controlling neonatal persistent pulmonary hypertension. Iran J Pediatr 2017;27(01):e6385

116 Walker DK, Ackland MJ, James GC, et al. Pharmacokinetics and metabolism of sildenafil in mouse, rat, rabbit, dog and man. Xenobiotica 1999;29(03):297-310

117 Mukherjee A, Dombi T, Wittke B, Lalonde R. Population pharmacokinetics of sildenafil in term neonates: evidence of rapid maturation of metabolic clearance in the early postnatal period. Clin Pharmacol Ther 2009;85(01):56-63

118 Baquero H, Soliz A, Neira F, Venegas ME, Sola A. Oral sildenafil in infants with persistent pulmonary hypertension of the newborn: a pilot randomized blinded study. Pediatrics 2006;117 (04):1077-1083

119 Vargas-Origel A, Gómez-Rodríguez G, Aldana-Valenzuela C, VelaHuerta MM, Alarcón-Santos SB, Amador-Licona N. The use of sildenafil in persistent pulmonary hypertension of the newborn. Am J Perinatol 2010;27(03):225-230

120 Herrera TR, Concha GP, Holberto CJ, Loera GRG, Rodríguez BI. Oral sildenafil as an alternative treatment in the persistent pulmonary hypertension in newborns. Revista Mexicana de Pediatria. 2006;73(04):159-163

121 Barst RJ, Beghetti M, Pulido T, et al; STARTS-2 Investigators. STARTS-2: long-term survival with oral sildenafil monotherapy in treatment-naive pediatric pulmonary arterial hypertension. Circulation 2014;129(19):1914-1923

122 FDA UFaDA. Revatio (sildenafil): Drug Safety Communication Recommendation Against Use in Children. 2012. Available at: 
http://www.fda.gov/Safety/MedWatch/SafetyInformation/SafetyAlertsforHumanMedicalProducts/ucm317743.htm. Accessed April 25, 2016

123 Abman SH, Kinsella JP, Rosenzweig EB, et al; Pediatric Pulmonary Hypertension Network (PPHNet). Implications of the U.S. Food and Drug Administration warning against the use of sildenafil for the treatment of pediatric pulmonary hypertension. Am J Respir Crit Care Med 2013;187(06):572-575

124 McElhinney DB. A new START for sildenafil in pediatric pulmonary hypertension: reframing the dose-survival relationship in the STARTS-2 trial. Circulation 2014;129(19):1905-1908

125 European Medicines Agency. Assessment report for Revatio, International Non-proprietary Name: sildenafil. Procedure No. EMEA/H/C/000638/II/0028. 2011. Available at: http://www.ema. europa.eu/docs/en_GB/document_library/EPAR_-_Assessment_ Report_-_Variation/human/000638/WC500107804.pdf. Accessed April 26, 2016

126 Samangaya RA, Mires G, Shennan A, et al. A randomised, doubleblinded, placebo-controlled study of the phosphodiesterase type 5 inhibitor sildenafil for the treatment of preeclampsia. Hypertens Pregnancy 2009;28(04):369-382

127 Maher MA, Sayyed TM, Elkhouly N. Sildenafil citrate therapy for oligohydramnios: a randomized controlled trial. Obstet Gynecol 2017;129(04):615-620

128 Ganzevoort W, Alfirevic Z, von Dadelszen P, et al. STRIDER: Sildenafil Therapy In Dismal prognosis Early-onset intrauterine growth Restriction-a protocol for a systematic review with individual participant data and aggregate data meta-analysis and trial sequential analysis. Syst Rev 2014;3:23

129 Chen J, Gong X, Chen P, Luo K, Zhang X. Effect of L-arginine and sildenafil citrate on intrauterine growth restriction fetuses: a meta-analysis. BMC Pregnancy Childbirth 2016;16:225
130 Maharaj CH, O'Toole D, Lynch T, et al. Effects and mechanisms of action of sildenafil citrate in human chorionic arteries. Reprod Biol Endocrinol 2009;7:34-34

131 Miller SL, Loose JM, Jenkin G, Wallace EM. The effects of sildenafil citrate (Viagra) on uterine blood flow and well being in the intrauterine growth-restricted fetus. Am J Obstet Gynecol 2009; 200(01):102.e1-102.e7

132 Inocencio I, Polglase G, Amy S, Mihelakis J, Miller S, Allison B. Long-term maternal sildenafil treatment increases sildenafil and endothelium independent mediated cerebral vasodilation in both fetal growth restricted and appropriately grown fetal lambs. J Paediatr Child Health 2017;53(S2):47-48

133 Zhu B, Strada S, Stevens T. Cyclic GMP-specific phosphodiesterase 5 regulates growth and apoptosis in pulmonary endothelial cells. Am J Physiol Lung Cell Mol Physiol 2005;289(02): L196-L206

134 Davey M, Shegu S, Danzer E, et al. Pulmonary arteriole muscularization in lambs with diaphragmatic hernia after combined tracheal occlusion/glucocorticoid therapy. Am J Obstet Gynecol 2007;197(04):381.e1-381.e7

135 Davey MG, Danzer E, Schwarz U, Adzick NS, Flake AW, Hedrick HL. Prenatal glucocorticoids and exogenous surfactant therapy improve respiratory function in lambs with severe diaphragmatic hernia following fetal tracheal occlusion. Pediatr Res 2006; 60(02):131-135

136 Delabaere A, Marceau G, Coste K, et al. Effects of tracheal occlusion with retinoic acid administration on normal lung development. Prenat Diagn 2017;37(05):427-434

137 Russo FM, Da Cunha MGMCM, Jimenez J, et al. 86: Synergic effect of maternal sildenafil and fetal\&\#xa0;tracheal occlusion improving pulmonary development in the rabbit model for congenital diaphragmatic hernia. Am J Obstet Gynecol; 216(01):S62 